Macacus, eight species of gibbons and one highly variable species of orang-all of East Asiatic origin, and none transgressing the 'Line'.

Whatever may be said about the inefficiency of the supposed boundary, it is evident that it has acted as a real barrier to far more mammals and mammalian groups than it has allowed to pass; and, in Raven's words, "this seems consistent with the fact that 'Wallace's Line' for the most part marks the eastern boundary of the ancient continent, while the islands east of it have had only occasional contacts with it. The facts suggest that those numerous families which failed to cross Wallace's Line only reached it in relatively modern times after the barrier was fully established".

Much has been done in the region since Alfred Russel Wallace published his observations and deductions in the sixties and seventies of last century, and the general run of investigation is to suggest that by narrow and temporary land bridges between deep seas, the islands of the Malay Archipelago made occasional contact with the old mainland of Cathaysia. So are explained the abundance of mammalian forms in the Malay Peninsula and Borneo, parts of the old mainland, and the relative scarcity of mammals in Celebes and the Philippine Islands, outliers of the continent. 'Wallace's Line' gains its significance and is a real boundary because it indicates the line of the continental shelf of the old mainland, and that marked the limit of distribution for most East Indian mammals. Van Kampen underestimated the significance of the 'Line', which Raven regards as being "well-established" by the distribution of mammals ; this refers more especially, as Gregory points out, to the southern two-thirds of the 'Line', for the northern end, where it runs south of the Philippines, appears to mark a break of more recent formation and of less zoogeographical significance.

JAMes Ritchie.

\title{
Royal Society of Canada
}

\section{Annual Meeting}

\section{$\mathrm{T}$} HE Royal Society of Canada held its annual meeting on May 21-24 at MeMaster University, Hamilton, Ontario. The presidential address by Prof. W. Lash Miller dealt with "Some Applications of the Methods of Physical Chemistry to the Study of Micro-organisms". The Flavelle Medal for 1934-35 was presented to Dr. F. T. Shutt, for his numerous contributions in the field of chemistry. The Lorne Pierce Medal was awarded to Dr. E. Montpetit, and the Tyrrell Medal to Brig.-General E. A. Cruikshank.

Prof. L. M. Gould, of Carleton College, Northfield, Minnesota, gave the annual public lecture, his subject being "Adventures in Antarctic Geology". Prof. Gould was a member of the recent Byrd expedition. His lecture was an outstanding humorous presentation of scientific facts.

In Section I (Literature française, Histoire, etc.) eighteen papers were presented, and seventeen in Section II (English Literature, History, etc.). Amongst a number of important contributions might be mentioned that of Dr. Lighthall on a newly discovered Journal of James and Andrew McGill. Besides supplementing greatly the hitherto scanty knowledge of James McGill, the founder of McGill University, this 522-folio-page work gives much information on the affairs of the North-West Fur Company from 1797 until 1814.

The contribution, "De l'influence de la révolu- tion americaine dans la province de Quebec" by Gustave Lanctot, and that by L. W. Howay on "Negro Immigration into Vancouver Island in 1850", served to emphasise the ever-present problem of the influence on Canada of political changes in the United States of America.

The feature of Section III (Mathematical, Chemical and Physical Sciences), which was held under the presidency of Prof. E. F. Burton, wass a symposium on supra-conductivity. Prof. Burton in his presidential address gave a summary of the general phenomena of supra-conductivity. $\mathrm{He}$ was followed by F. G. A. Tarr, who spoke on the magnetic effects in supra-conductors, and announced that he finds the effective permeability to be influenced by the geometrical shape of the body. A. D. Misener gave results of experiments which indicated that the transition point for thin films of lead is a function of the thickness of the film. The results of experimental work done at the cryogenic laboratory at Toronto were summarised, and this was followed by three theoretical papers on the explanation of supraconductivity, by C. Barnes; H. Grayson Smith and Prof. L. V. King. Prof. King's theory, founded on electric polarisation and space lattices, was an important contribution; the theoretical curves for the Wiedemann-Franz relation and the effect of a magnetic field on the transition temperature 
are in satisfactory agreement with experimental results.

Among the hundred and twenty-nine papers presented to the section, space permits the mention of only a few. Prof. L. V. King presented a paper on the theory of acoustical resonators in which he succeeded in obtaining an exact solution for the case of a semi-infinite cylinder bounded by an infinite flange. The agreement with Rayleigh's approximation is excellent. Dr. L. Gilchrist and his collaborators presented two papers on the results of applied geophysical work and Dr. H. G. I. Watson spoke on an improved electrical method of using the point electrode in geophysical field work. A paper by Prof. J. Satterly and J. C. Strachan on the measurement of surface tension of water and mercury by means of stationary waves on a vertical jet was the subject of an interesting theoretical discussion as a result of the values obtained for mercury by this method. Dr. Otto Maass presented a paper in collaboration with W. H. Barnes and R. S. Brown giving the results of determinations of the specific heat of liquid $\mathrm{D}_{2} \mathrm{O}$ from $0^{\circ}$ to $100^{\circ} \mathrm{C}$. Among the several papers by Dr. O. Maass and his associates, mention may be made of an interesting investigation on the dielectric constants of propylene and methyl ether for both the liquid and vapour forms from room temperature to $10^{\circ} \mathrm{C}$. above their critical temperatures. A definite difference in dielectric constant of liquid and vapour has been found to persist above the critical temperature.

Dr. J. A. Gray and J. S. Marshall presented papers on the scattering of $\beta$-rays in which the loss of energy by a homogeneous beam scattered through an angle of approximately $90^{\circ}$ is measured and the absorption in aluminium of homogeneous $\beta$-rays determined. Further results on the study of pleochroic haloes were presented by Dr. G. H. Henderson. Evidence for instabilities resembling eddies in the striated discharge from measurements made using a small Rayleigh disc was given in a paper by Dr. D. A. Keys. Dr. G. M. Shrum gave an account of a method of finding the vitamin A content of pilchard oil from the absorption spectrum. Dr. D. C. Rose read an interesting paper summarising the results of a series of continuous records of atmospheric potential gradient, taken at Ottawa, which show a relation between weather conditions and the deviations from the average type of diurnal variations. In a paper presented by J. O. Wilhelm, A. D. Misener and A. R. Clark, the results of viscosity measurements on the two forms of liquid helium were given. Helium I at $2 \cdot 3^{\circ} \mathrm{K}$. has a viscosity of $0 \cdot 00027$ c.G.S. units and helium II at $2 \cdot 2^{\circ} \mathrm{K}$. has a viscosity of 0.000033 c.G.s. units, which is not very different from that of helium gas. Several papers on spectroscopy, particularly on the hyperfine structure of lines, were presented by Dr. Stanley Smith, A. B. McLay, M. F. Crawford and others. An exceptionally interesting series of papers was presented in Section IV, and the following list of subjects discussed indicates their wide range of geological interest :

Physiology of northern British Columbia; the deformation of post-glacial lake terraces in Ontario ; problems in stratigraphy in the complex series of southern Quebec; a late Cretaceous fauna of southern Alberta; a revision of the genus Tetradium; a revision of the genus Calapoecia; a discussion of Archæo-cyathinæ; the differentiation and structural history of the Sudbury Nickel Irruptive; heavy accessory minerals in granites; igneous breccias; new types of pleochroic haloes and their causes; the composition of asbestos and related fibres; rock flour glacial 'White Silts' in southern British Columbia; fabric analysis in structural petrology; and geological deductions from deep focal earthquakes.

The meeting was brought to a fitting close by an excursion to examine the interesting geological features in the vicinity of Hamilton.

Prof. John Tait in his presidential address to Section V (Biological Sciences) spoke on "Some Structural Implications of the Respiratory Mechanism in Animals", and illustrated his viewpoint with examples from a very wide range of organisms. Eighty-six papers were presented in this section; Sir Frederick Banting, Prof. C. H. Best, Prof. E. M. Walker and their respective collaborators presented work on varied endocrinological and related subjects, which included respiratory metabolism and poisons; salt secretion; the site of formation of the phosphates of blood serum ; the phosphoric esters of normal and malignant tissues; the biological effects of sericite and various other mine dusts ; and the respiratory metabolism of the seal. Prof. J. B. Collip and his collaborators presented work on endocrine interrelations during pregnancy; the influence of prolonged administration of an anterior pituitary extract on the ketosis of experimental diabetes; the production of endometrial moles through operation on the rat uterus during the second part of pregnancy; the nature of the constitutional factor in chronic atrophic rhinitis; and a number of other papers on the effects of various hormone extracts. Dr. J. S. L. Browne and E. M. Venning showed the effects of various treatments on normal and ovariectomised women. Prof. H. Wasteneys and his colleagues presented papers on factors affecting the rate of protein breakdown and on the synthetic action of pancreatic lipase, together with reports on new biochemical techniques. Prof. D. T. Fraser and colleagues gave an interesting 
group of papers on sera and toxins. Prof. P. Masson spoke on "La multiplicité probable des syncytium de Schwann".

Papers of a general zoological or botanical nature numbered thirty-one. Prof. Marie-Victorin, J. Rousseau and J. Brunel gave the results of systematic studies of the Quebec flora. Prof. R. B. Thomson presented a new interpretation of the segmental organisation of Osmunda and Prof. H. S. Jackson described variations in the short-cycle rusts; with their colleagues and students they presented a series of other papers on plant anatomy and mycology. Dr. J. H. Craigie gave an exhaustive account of the epidemiology of wheat stem rust. Dr. J. W. McArthur presented data on tomatoes which are of great significance for general theories of the inheritance of quantative characters. Dr.
L. O. Gaiser showed the occurrence of different chromosome numbers in various wild populations of Liatris punctata. Prof. A. H. R. Buller reviewed our knowledge of the sclerotia of the higher fungi. Prof. G. H. Scarth and J. Levitt described a method of measuring water permeability of freed plant protoplasts and gave new data on the problem of cell permeability in relation to hardiness.

A dinner in honour of Prof. Wilson Smith, professor of botany at McMaster University, who is retiring this year, and various field excursions were interesting features for this Section.

The social arrangements made by McMaster University and local residents, and the facilities for accommodation, exhibits and meetings provided by the splendid new buildings of the University were much appreciated.

\section{Obituary}

\section{Prof. B. L. Robinson}

$\mathrm{F}^{2}$ LORISTIC botany suffered a heavy loss by the death on July 27 of Benjamin Lincoln Robinson. Born at Bloomington, Illinois, on November 8, 1864, he graduated A.B. at Harvard in 1887, and then studied under de Bary at Strassburg, where he took the Ph.D. in 1889. His early work was anatomical, especially on unusual stem-anatomy; his thesis was on the stem-anatomy of Phytocrene macrophylla.

Returning to Harvard, Robinson became assistant in the Gray Herbarium under Sereno Watson, and on Watson's death in 1892 was appointed curator. The development of the Herbarium and the continuation of the taxonomic researches on American botany begun by Gray and continued by Watson have been Robinson's life-work. He found the Herbarium poorly housed, inadequately equipped, with a meagre endowment, and no definite status in the University. By the aid of generous donors he was able, during the years 1909-15, gradually to replace the little old building by an imposing modern structure which has been described as the safest and most conveniently arranged and best equipped herbarium building in the world. The endowment in 1899, by Mrs. Gray, of an Asa Gray professorship of systematic botany, of which Robinson was the first incumbent, added instruction to the functions of the Herbarium.

Two important pieces of work demanded attention when Robinson became curator-the completion of Gray's "Synoptical Flora of North America", and a much needed revision of Gray's "Manual of Botany". The former, with the aid of several experienced botanists, was completed in 1895-97, and the latter in conjunction with M. L. Fernald in 1908.

The results of Robinson's work and that of his assistants, on the floras of North America, Mexico and tropical South America, are embodied in a long series of papers in the Proceedings of the American Academy of Arts and Sciences and other periodicals. The substantial volumes of the reprints collected in the convenient form of "Contributions from the Gray Herbarium" are a monument to their industry. Robinson was specially fond of the Compositæ, and his "Revision of the genus Brickellia" was the first of the larger "Memoirs of the Gray Herbarium" begun in 1907.

Robinson's interest in local and regional botany found expression in the New England Botanical Club started in Boston in 1895, and for thirty years after its inception in $\mathbf{1 8 9 9}$ he edited its journal, Rhodora. The Club collection lodged in the Gray Herbarium numbers more than 150,000 sheets.

British botanists showed their appreciation of Robinson's work by electing him to the foreign membership of the Linnean Society of London in 1922. His colleagues and friends at home and abroad will regret the passing of an eminently sane critical botanist and a courteous and kindly gentleman.

\section{A. B. RENDLE.}

WE regret to announce the following deaths :

Lieut.-Colonel H. W. Acton, C.I.E., formerly director of the School of Tropical Medicine, Calcutta, on August 23, aged fifty-two years.

Prof. Henry Briggs, O.B.E., Hood professor of mining in the University of Edinburgh since 1924, and professor of mining in Heriot-Watt College since 1919, on August 24, aged fifty-two years.

Prof. E. Jeanselme, emeritus professor in the faculty of medicine in the University of Paris, known for his work on syphilis, leprosy, and the history of medicine, aged seventy-seven years. 